\title{
9. EVOLUTION OF THE CALCAREOUS NANNOFOSSIL ASSEMBLAGE AS A RESPONSE TO THE PALEOCEANOGRAPHIC CHANGES IN THE EASTERN EQUATORIAL PACIFIC OCEAN FROM 4 TO 2 Ma (LEG 138, SITES 849 AND 852) ${ }^{1}$
}

\author{
J.A. Flores, ${ }^{2}$ F.J. Sierro, ${ }^{2}$ and I. Raffi ${ }^{3}$
}

\begin{abstract}
Variations in the accumulation rate and preservation of late Pliocene calcareous nannofossils from the eastern equatorial Pacific Ocean are studied. Increases in the accumulation rate of nannofossils, are related to changes in paleoproductivity which in turn are linked to paleoceanographic change. Maxima in fluxes of nannofossils observed from 3.50 to 3.40 and 3.10 to 2.65 $\mathrm{Ma}$ are interpreted as periods of high paleoproductivity. The nannofossil accumulation rate at Site 849, an area of oceanic divergence, on average is 10 times higher than that recorded at Site 852 (convergence area). Moreover, dissolution intensity is greater at Site 852. Times of greater dissolution at Site 852, characterized by high percentages of asteroliths, generally coincide with times of lower nannofossil accumulation rates at Site 849. Therefore, we assume that productivity and dissolution may be inversely related because the carbonate compensation depth (CCD) and the lysocline are deeper in the equatorial divergence region as a result of the higher carbonate supply in this region.

The accumulation rate of asteroliths have a similar rank in both sites, allowing us to conclude that this group is relatively more abundant in the region of lower productivity, whereas it has been diluted in the higher productivity area.

A remarkable event is identified at 3.20 Ma in both sites. The reentry of the cool water species Coccolithus pelagicus coincides with a shoaling of the $\mathrm{CCD}$, which may indicate a major paleoceanographic change in the eastern equatorial Pacific Ocean. Northward and southward currents may have been established or intensified at this age, introducing cool elements in the nannofossil assemblage at the same time that the Atlantic-Pacific connection become restricted through the Panamanian Corridor.

The accumulation rate of Pseudoemiliania lacunosa follows a similar trend as that of $C$. pelagicus. Its high fluxes during globally recognized cool periods lead us to infer that it is linked to low-temperature surface waters.

Between 4 and $2 \mathrm{Ma}$, a similar pattern of nannofossil accumulation rates is observed in the divergence and convergence areas, suggesting that a general model explains any variations in eastern equatorial Pacific Ocean.
\end{abstract}

\section{INTRODUCTION}

Leg 138 (eastern equatorial Pacific) was the fifth in a series of Ocean Drilling Program (ODP) expeditions to the tropical ocean that focused on examining the evolution of climatic change and paleoceanography throughout the late Cenozoic period.

Leg 138 drill sites (Fig. 1) are located in the region influenced by the eastern equatorial Pacific Ocean circulation system. This system is responsible for more than half the global primary production (Chavez and Barber, 1987) and is sensitive to climatic and paleoceanographic change. In this area, the North Equatorial Countercurrent (NECC), which is depleted in nutrients, flows from the western Pacific eastward into the eastern tropical Pacific at about 5N. The South Equatorial Current (SEC) carries nutrient-rich waters from the South American margin. At the Equator, the divergence of surface waters forces an upwelling of subsurface waters to bring nutrients up into the euphotic zone. Today's oceanographic pattern in the area is mainly conditioned by the atmospheric circulation and the position of the Intertropical Convergence (ITC) (Pisias and Prell, 1985).

The following were high-priority scientific questions addressed during Leg 138 (Mayer, Pisias, Janecek, et al., 1992):

1. How did Pacific Ocean equatorial circulation evolve through the late Cenozoic as a response to increased global glaciation?

2. What was the nature of the circulation system during the late Miocene, when open communication with the Atlantic Ocean occurred through the Panamanian seaway?

'Pisias, N.B., Mayer, L.A., Janecek, T.R., Palmer-Julson, A., and van Andel, T.H. (Eds.), 1995. Proc. ODP, Sci. Results, 138: College Station, TX (Ocean Drilling Program).

${ }^{2}$ Universidad de Salamanca, Spain.

${ }^{3}$ Servizio Geologico/Università de Parma, Italy.

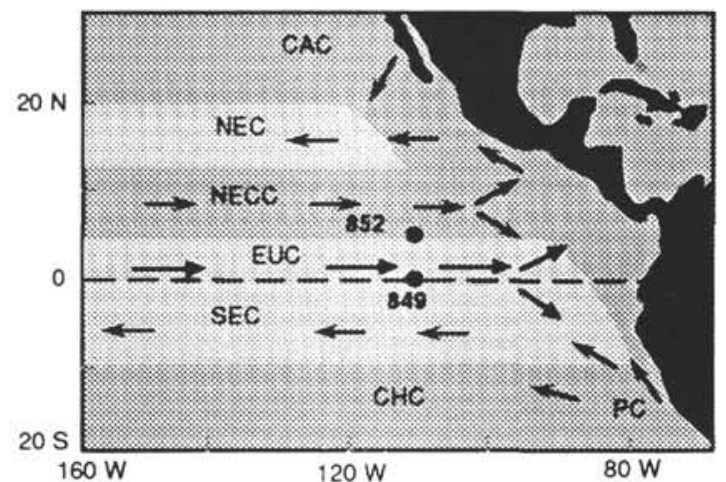

Figure 1. Location map for Sites 849 and 852 and generalized circulation system of the eastern equatorial Pacific Ocean. Surface currents: CAC = California Current; $\mathrm{NEC}=$ North Equatorial Current; $\mathrm{NECC}=$ North Equatorial Countercurrent; $\mathrm{SEC}=$ South Equatorial Current; $\mathrm{PC}=$ Peru Current; and $\mathrm{CHC}=$ Chile Current. Subsurface current: EUC $=$ Equatorial Undercurrent.

3. What was the nature of oceanographic variability during the Pliocene and how does this compare with the Pleistocene?

4. How did oceanographic changes affect productivity in the Equatorial Pacific Ocean surface waters?

In the sites drilled during Leg 138, calcareous nannofossils are abundant (Mayer, Pisias, Janecek, et al., 1992) and preservation is generally good. Raffi and Flores (this volume) show that nannofossils are useful as biostratigraphic tools. Furthermore, as primary producers living in the surface waters of the ocean, calcareous nannofossils react to climatic and paleoceanographic changes. Some groups of nannofossils, such as the asteroliths, are sensitive indicators of climate 
change or variations in the nutrient content of near surface waters (Backman and Pestiaux, 1987; Chepstow-Lusty et al., 1989 and 1992). These climatic and paleoceanographic changes, in turn, are related to variability in astronomical parameters through the Pliocene. Nannofossil abundance, assemblage change, and preservation are also controlled by the degree of carbonate dissolution in the deep ocean and in the sediments (Farrell et al., this volume). Dissolution and paleoproductivity variations also are useful indicators of paleoceanographic change (Pisias and Prell, 1985b; Theyer et al., 1985; Farrell and Prell, 1991).

The main goals of this study are (1) to evaluate variations that occur in the total assemblage (thanatocenosis) of nannofossils, including characteristic groups or species such as asteroliths, Coccolithus pelagicus (Wallich) Schiller, medium and large reticulofenestrids (MR and LR), joined to other morphotypes as small (SR) and very small reticulofenestrids (VSR), and their relationships to important paleoceanographic and climatic events; (2) to study surface water productivity changes via nannofossil assemblage variations; and (3) to evaluate the effect of dissolution on nannofossil assemblages and link this to paleoceanographic parameters.

To fulfill our objectives, two sites from the western transect were chosen (Sites 849 and 852) located within the divergence and convergence regions, respectively (Fig. 1). The interval analyzed is within the late Pliocene, beginning at about the last appearance datum (LAD) of Reticulofenestra pseudoumbilicus (Gartner) Haq and Berggren and ending immediately before the extinction of the asteroliths, between 4 and $2 \mathrm{Ma}$ (according to Shackleton et al. and Raffi and Flores, this volume).

\section{MATERIAL AND METHODS}

Based on preliminary shipboard data (Mayer, Pisias, Janecek, et al., 1992), a sampling resolution of approximately 8 k.y. was considered appropriate for this study. This represents a sampling interval of 10 and $20 \mathrm{~cm}$, for Sites 852 and 849 , respectively. In both sites, composite depths (Hagelberg et al., 1992) and samples from two holes were used to construct a continuous interval. Figure 2 indicates the holes and cores involved.

\section{Site 849}

Today, Site 849 is located in the equatorial divergence area $\left(0^{\circ}\right.$ of latitude). The site was chosen to provide a good record of environmental and evolutionary change in the late Pliocene in a high-productivity area. The backtracked paths for the last 4 m.y. show that this site stayed in the same latitude (van Andel et al., 1975; Pisias et al., this volume). The site depth $(3850 \mathrm{~m})$ is presently located below the lysocline but above the carbonate compensation depth (CCD). Subsidence of Site 849 and variations in the depths of the lysocline and the CCD have undoubtedly affected the degree of preservation of the nannofossils. The late Pliocene lithology is uniform and consists mainly of nannofossil oozes, with a small and variable amount of diatoms and foraminifers.

According to Shackleton et al. (1992), the sedimentation rate for this interval (4-2 Ma) varies to about $2.65 \mathrm{~cm} \mathrm{k.y.}{ }^{-1}$. The sediment mass accumulation rate (MAR) for the same interval averages $2 \mathrm{~g}$ $\mathrm{cm}^{-2}$ k.y. ${ }^{-1}$.

\section{Site 852}

Site 852 is located in an area of oceanic convergence, close to the boundary between the SEC (flowing westward) and the NECC (flowing eastward ) (Fig. 1). The backtracked path (van Andel et al., 1975; Duncan and Clague, 1985; Pisias et al., this volume) indicates that this site has always been north of the Equator, outside the area

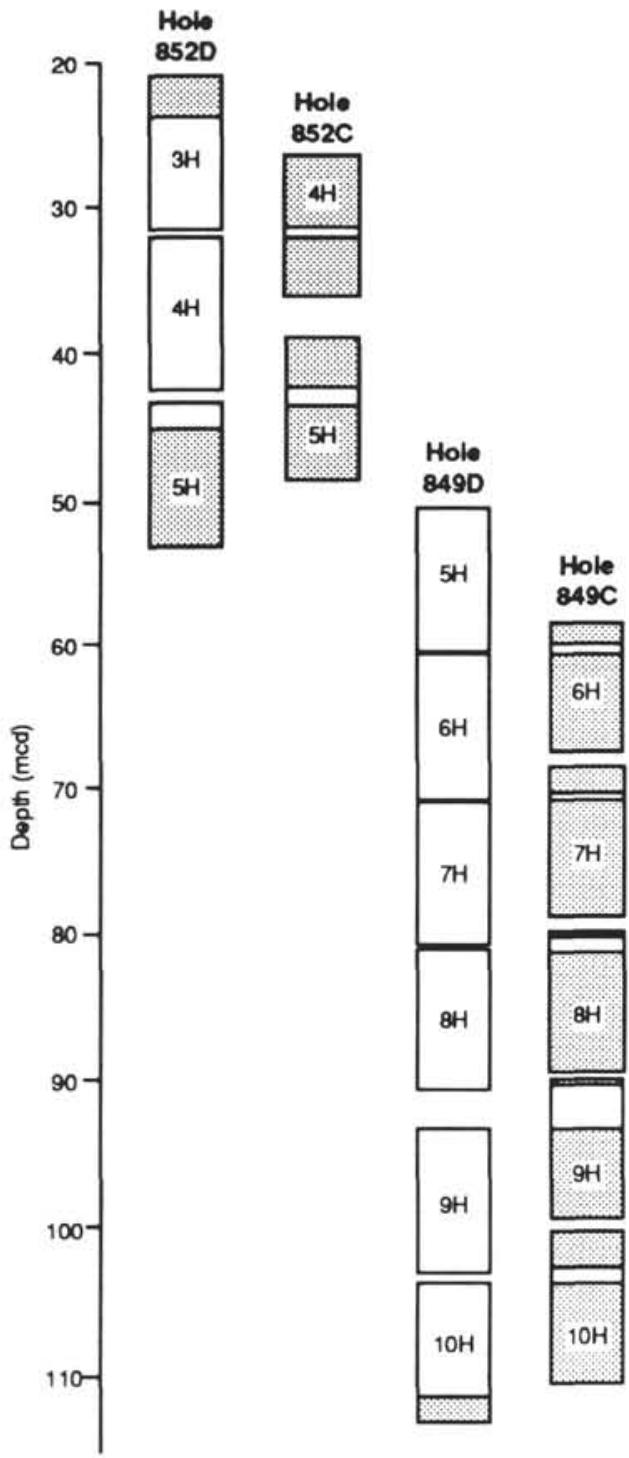

Figure 2. Holes and depth intervals (in composite depth) selected for high resolution study of calcareous nannofossils. The shaded area represents intervals that were not sampled.

influenced by equatorial divergence. The site lies at a depth of 3872 $\mathrm{m}$, below the modern lysocline.

The sediment that accumulated between 4 and $2 \mathrm{Ma}$ at Site 852 consists of nannofossil and foraminifer muds, with interbedded clay layers. According to Shackleton et al. (1992), the average sedimenta-

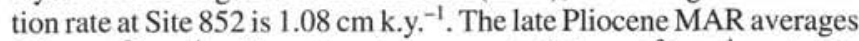
$0.7 \mathrm{~g} \mathrm{~cm}^{-2} \mathrm{k.y} .^{-1}$, with scattered decreases to $0.5 \mathrm{~g} \mathrm{~cm}^{-2} \mathrm{k} . \mathrm{y}^{-1}$, probably from dissolution. In the interval considered, fluctuations in the content of $\mathrm{CaCO}_{3}$, silica, and clay may reflect local or regional changes in bottom-water chemistry. By comparison with Site 849 data, one might say that dissolution is a regional phenomenon (Mayer, Pisias, Janecek, et al., 1992).

\section{Techniques}

With the aim of estimating the variability in the nannofossil assemblage, the processing procedure shown in Figure 3 was followed. Starting from a roughly uniform sediment, with this procedure 


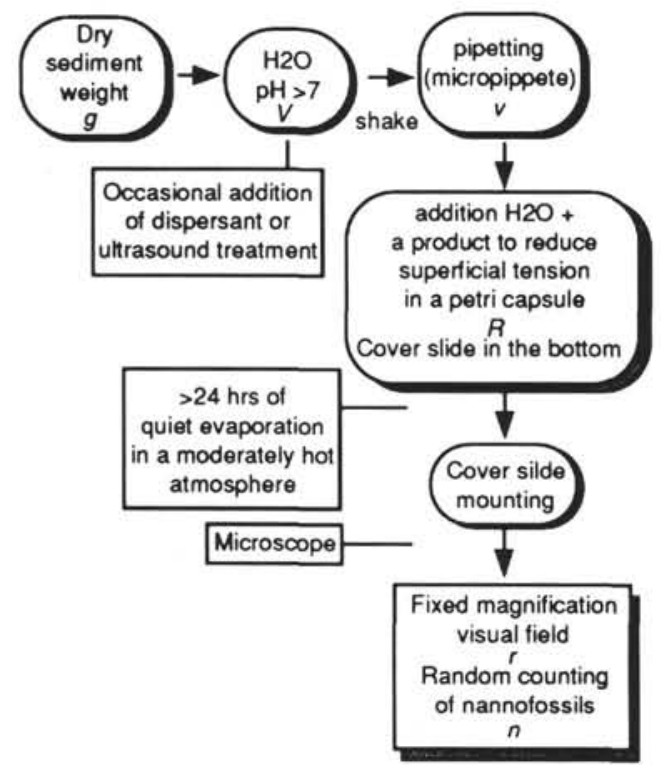

Figure 3. Flow diagram showing the procedure used to obtain the total number of nannofossils per gram of dry sediment: $g=$ the dry sediment weight; $V=$ volume of water added to the dry sediment; $v=$ volume of mixture taken out with a micropipette; $R=$ radius of the petri dish used; $r=$ radius of the visual field used in the counting and $n=$ number of nannofossils counted in a random by scanned area. we tried to calculate the number of nannofossils $(n)$ per gram of sediment. Knowing this and the mass accumulation rate (MAR) we can determine the nannofossil accumulation rates (total and by species or species group).

This technique follows the scenario discussed by Flores and Sierro (1989) and a procedure similar to that of Wei (1988) with some modifications. The major changes we introduced were to obtain a more homogeneous distribution.

From Equation 1, the total number of nannofossils per gram of dry sediment is obtained:

$$
T=n R^{2} V r^{-2} g^{-1} v^{-1} .
$$

The analyses were performed using a petrographic microscope with a magnification of $1250 \times$. Around 400 nannofossils larger than $3 \mu \mathrm{m}$ were counted randomly. According to Patterson and Fishbein (1989), for a probability failure of $1 \%$, forms in abundance of more than $1 \%$ are recorded. A second scan was performed in two transects to detect forms that appear in low abundance, but are biostratigraphically useful. Nannofossils smaller than $3 \mu \mathrm{m}$, dominant in the assemblage, were counted by analyzing the same number of visual fields used to count the larger forms. This procedure allowed us to avoid the noise that these small forms can introduce. To identify some biostratigraphic datums, such as the different asterolith events, a special counting of more than 100 nannoliths was considered.

The nannofossil accumulation rate was calculated following the procedure used by Mayer, Pisias, Janecek, et al. (1992) as

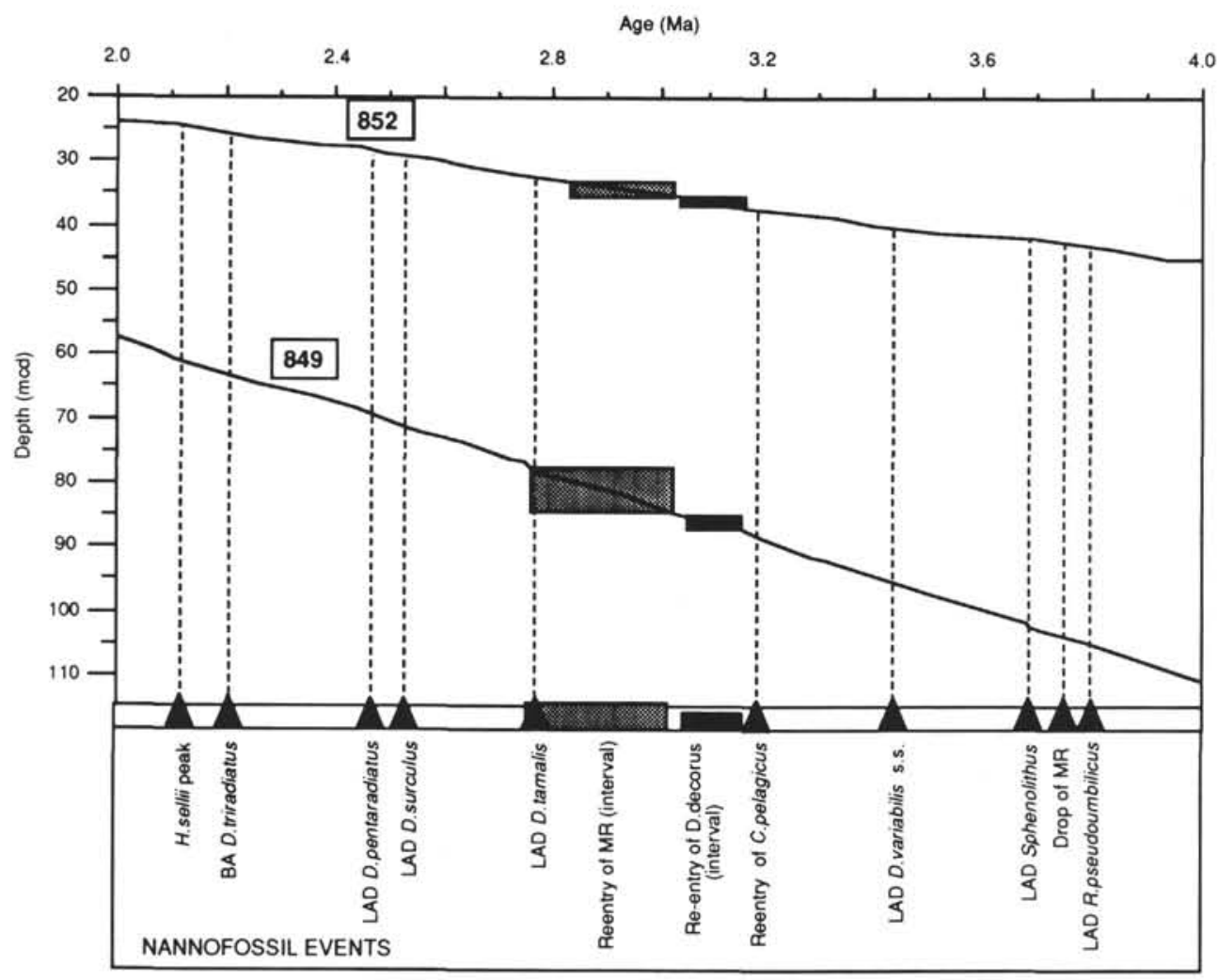

Figure 4. Sedimentation rates and position of the main nannofossil events, according to the scale of Shackleton et al. (this volume). Detailed information appears in Table 1. MR = medium reticulofenestrids (see the Appendix). 

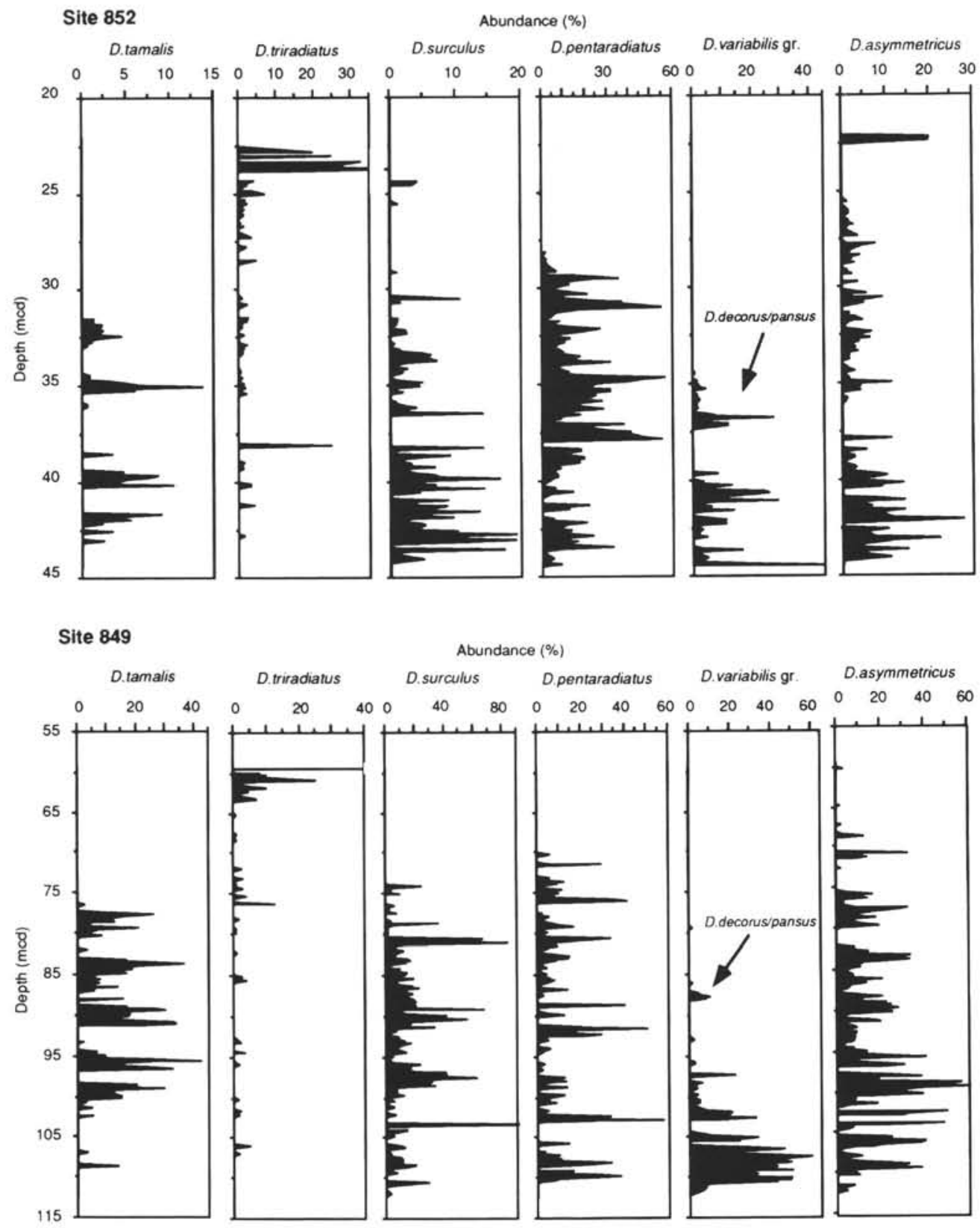

Figure 5. Abundance of the most biostratigraphically significant species or groups of asteroliths in Sites 849 and 852 . To calculate their percentages, more than 100 asteroliths were counted. Discoaster brouweri is not plotted.

nannofossils $/ \mathrm{g} \times$ dry-bulk density $\left(\mathrm{g} / \mathrm{cm}^{3}\right)$

$\times$ linear sedimentation rate $(\mathrm{cm} / \mathrm{k} . \mathrm{y})=$. nannofossils $/ \mathrm{cm}^{2} / \mathrm{k} . \mathrm{y}$.

We used the sedimentation rates estimated from the age model of Shackleton et al. (this volume). The dry-bulk density for every sample was obtained by linear interpolation between the values recorded on board the ship.

\section{Age Model}

Here, we use the age model presented by Shackleton et al. (this volume). This model was made using the calibration of the magnetostratigraphic and biostratigraphic events, and the composite GRAPE record (Hagelberg et al., this volume) compared with the calculated variations in solar insolation (Berger and Loutre, 1991).
In Figure 4, the most important nannofossil events are located according to the age model proposed for both sites. Peculiarities, diachronism, and other characteristics are commented upon in the text.

\section{BIOSTRATIGRAPHIC REMARKS}

The most important nannofossil biostratigraphic events are presented and discussed by Raffi and Flores (this volume). Here, we have calibrated these conventional events and other changes in nannofossil groups with Shackleton et al.'s scale (this volume) (Table 1 and Fig. 4). Quantitative analyses were performed to determine the location of the events (Figs. 5 and 6). Small diachronisms may be the result of sampling resolution, preservational effects or small errors in the time scale. Taxonomic comments about some of these species appear in the Appendix. 

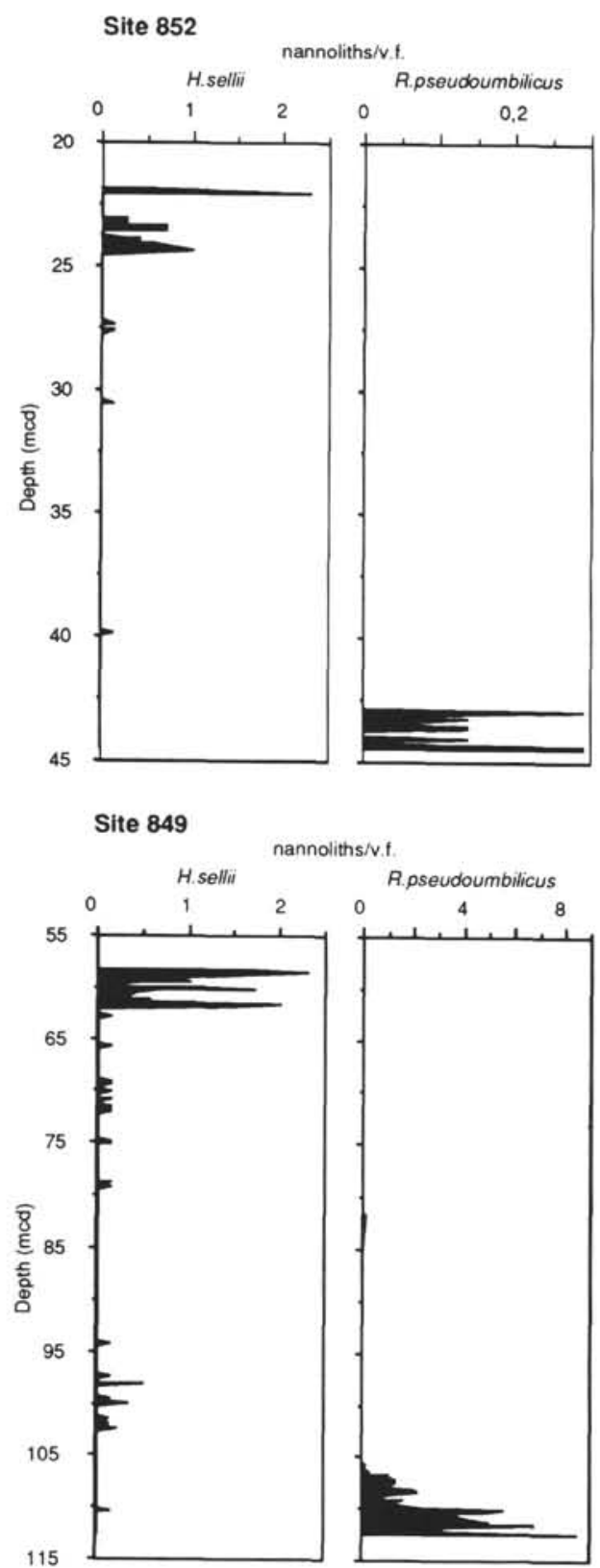

Figure 6. Abundance of Helicosphaera sellii and Reticulofenestra pseudoumbilicus relative to the total number of nannofossils at Sites 849 and 852 .

\section{RESULTS: THE NANNOFOSSIL SIGNAL}

The most numerically and stratigraphically significant calcareous nannofossil groups have been examined (Figs. 7 through 16). Systematic aspects and/or definitions of the groups are presented in the Appendix. A detailed list of the species recorded appears in Raffi and Flores (this volume).

\section{Total Nannofossils and Very Small Reticulofenestrids}

In Sites 849 and 852 , the nannofossil assemblages are predominantly very small reticulofenestrids (VSR). VSR always appear in higher proportion than the small reticulofenestrids (SR) and medium reticulofenestrids (MR) or other groups of nannofossils. The high abundance of the VSR and their sensitivity to dissolution makes the VSR an interesting group to study in terms of nannofossil production and preservation. Because of their abundance, VSR and total nannofossils have a parallel distribution (Figs. 7 and 8).

Important differences were observed in the VSR and accumulation rates of total nannofossils between Sites 849 and 852 . Site 849 exhibits high nannofossil fluxes and generally good preservation. In Site 852, intervals having good or moderate preservation alternate with those of poor preservation (dissolved). Even in the well-preserved intervals at Site 852, nannofossil accumulation rates are 5 to 10 times less than those recorded in Site 849 (Fig. 7). Higher fluxes in Site 849 are observed at 3.55 to $3.35,2.87$ to 2.60 , and 2.48 to $2.12 \mathrm{Ma}$, whereas lower values appear at about 3.20 and $2.50 \mathrm{Ma}$. In Site 852, the interval prior to 3.20 Ma shows a high degree of dissolution, although dissolution is less severe in the interval between 3.48 and $3.40 \mathrm{Ma}$. From 3.20 to $2.65 \mathrm{Ma}$, the VSR flux at Site 852 follows a similar trend as that seen in Site 849 , while from 2.65 Ma upward, an inverse pattern was observed (Fig. 8).

\section{Small and Medium Reticulofenestrids}

The abundance of reticulofenestrids larger than $3 \mu \mathrm{m}$, excluding Pseudoemiliania lacunosa (Kamptner) Gartner (see the Appendix), shows a similar pattern in both sites (Figs. 9 and 10). The strong reduction at about $3.70 \mathrm{Ma}$ of the accumulation rates of MR (see the Appendix) is followed by the reentry of this group between 3.02 and $2.76 \mathrm{Ma}$. In the same interval, an increase of the SR flux occurs. Since $2.76 \mathrm{Ma}$, the occurrence is scattered (Figs. 9 and 10).

\section{Pseudoemiliania lacunosa}

At Site 849, we observe a maxima of Pseudoemiliania lacunosa between 3.30 to $3.05 \mathrm{Ma}$ that is situated between two minima spanning from 4.0 and $3.70 \mathrm{Ma}$ and 3.30 and $3.05 \mathrm{Ma}$. At $2.80 \mathrm{Ma}$, the increase of this group is important in both sites (Fig. 11). We observe an inverse distribution of this taxon compared to SR and MR. Specimens of Pseudoemiliania lacunosa of medium size (see the Appendix) have a flux distribution that is opposite that of the MR and SR (Figs. 9, 10, and 11).

\section{Coccolithus pelagicus}

This taxon shows a particularly interesting time distribution. It occurred regularly during the Miocene and late Pliocene, but was completely absent during most of the early Pliocene in the eastern equatorial Pacific Ocean (Pujos, 1985; Raffi and Flores, this volume). A reentry of this species was observed at $3.20 \mathrm{Ma}$ in Site 849 and at about 3.17 Ma in Site 852 (Fig. 12). This minor diachronism may be attributed to the strong dissolution at Site 852 . At about $3.15 \mathrm{Ma}$, a sharp increase in Coccolithus pelagicus was observed at both sites. Although other punctuated increases in the accumulation rate of this species are recorded after $2.60 \mathrm{Ma}$ at both sites, they are not synchronous in the two sites.

\section{Other Species}

Calcidiscus leptoporus (Murray and Blackman) Loeblich and Tappan is an abundant species in the nannofossiliferous assemblage. High accumulation rates occurred between 4.0 and 3.20 and 3.08 ( 2.90 in Site 849 ) to $2.71 \mathrm{Ma}$, and a significant minimum occurs at 3.20 Ma. With the exception of the dissolved intervals, small differences can be observed in the distribution at both sites (although the absolute number are much greater at Site 849) (Fig. 13).

A similar pattern was observed in the accumulation rate of Helicosphaera carteri (Wallich) Kamptner. Low values are recorded at about 3.20 and $2.39 \mathrm{Ma}$, and a peak characterizes the interval from 3.05 to 2.65 (in Site 852) and from 2.90 to $2.65 \mathrm{Ma}$ (in Site 849). Dissolution precludes a perfect correlation; however, the curves exhibit similar trends in both sites (Fig. 14). 


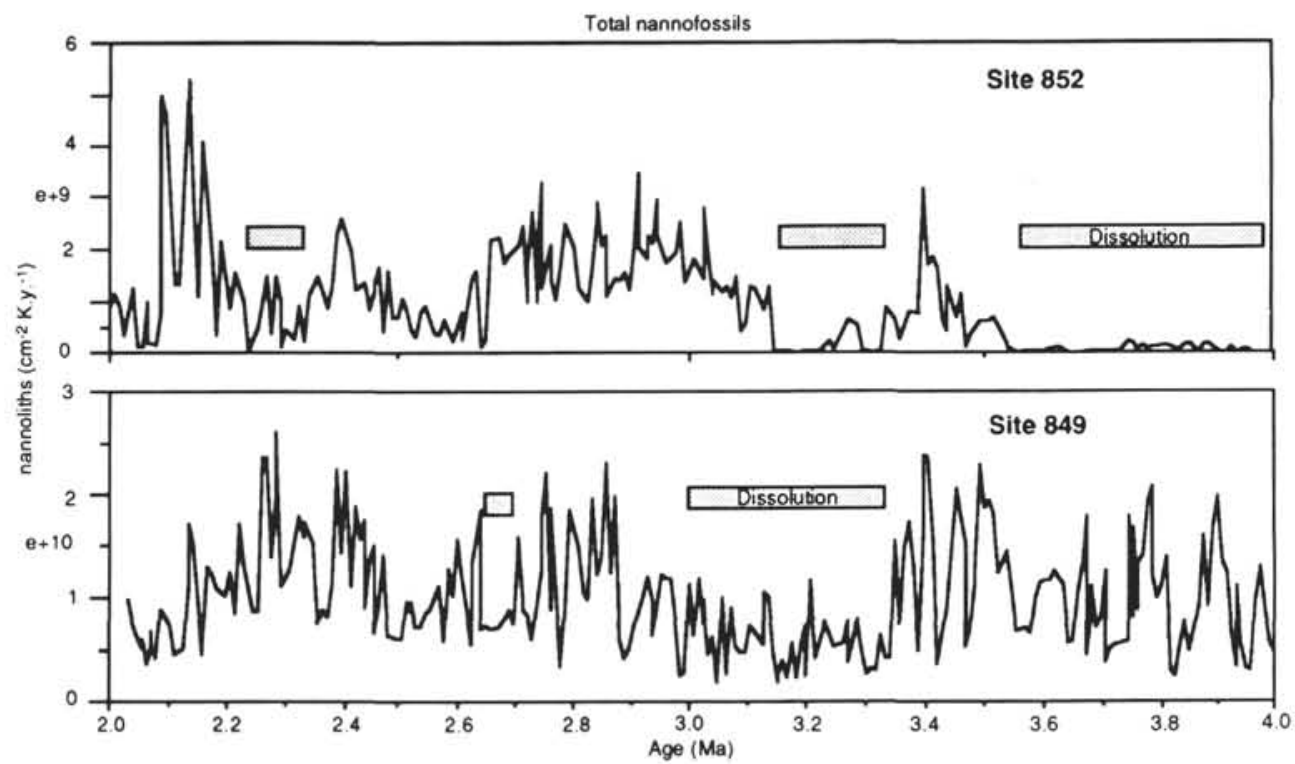

Figure 7. Total nannofossil accumulation rates at Sites 849 and 852 from 4 to $2 \mathrm{Ma}$. Bars represent dissolved intervals.

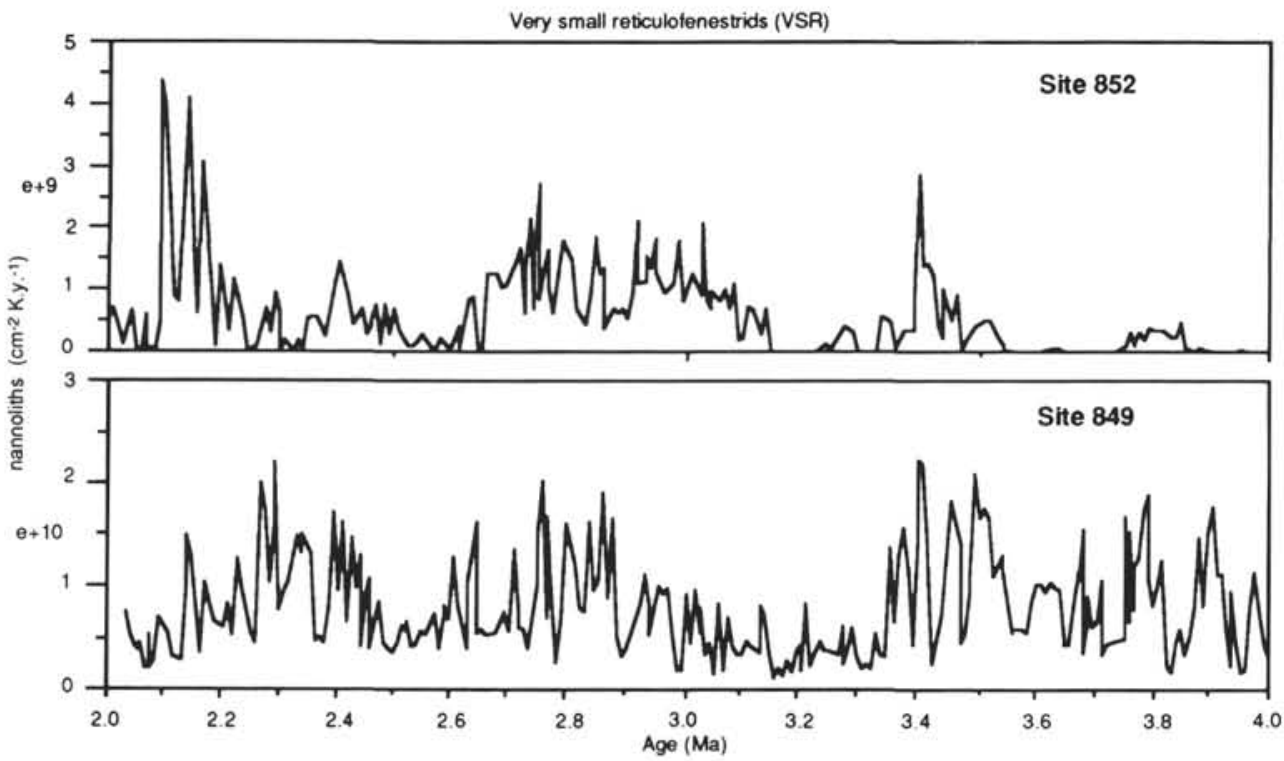

Figure 8 . Very small reticulofenestrid accumulation rates at Sites 849 and 852 between 4 and 2 Ma. For taxonomic information, see the Appendix and Table Al.

The pattern of variation of Geminilithella rotula (Kamptner) Backman is different in both sites. This taxon has a low resistance to dissolution, and is less abundant at Site 852 than in Site 849. At Site 849 , accumulation peak at around $3.55 \mathrm{Ma}$ is followed by a progressive decrease (Fig. 15).

\section{Asteroliths}

The whole group as well as selected species and morphotypes have been studied. Since the asteroliths are a dissolution-resistant group, the accumulation rate can be compared in both sites, even in the dissolved intervals.

When considering the total asteroliths in both sites, the following facts should be taken into account: (1) we observe relatively high abundances in Site 852 compared to Site 849 (Figs. 16 and 17), (2) the highest accumulation rates in both sites and similar fluxes are found in the following intervals 3.50 to $3.32,3.17$ to 2.76 (with a minimum around 3.0 Ma) and 2.48 to $2.15 \mathrm{Ma}$ (Fig. 16), and (3) an opposite distribution, compared to the VSR was observed in most of the upper Pliocene sediments (Figs. 16 and 8).

Several events have been detected in Sites 852 and 849 and are summarized in the "Biostratigraphic Remarks" section (this chapter) and in Table 1. Details about systematic taxonomy appear in the Appendix.

Discoaster tamalis Kamptner and Discoaster asymmetricus Gartner, irregularly distributed, exhibit parallel variations as shown previously Backman and Shackleton (1983), Backman et al. (1986), Backman and Pestiaux (1987), and Chepstow-Lusty et al. (1989) (Fig. 5). At Site 849, peaks in their relative abundance were detected in the intervals 3.70 to 


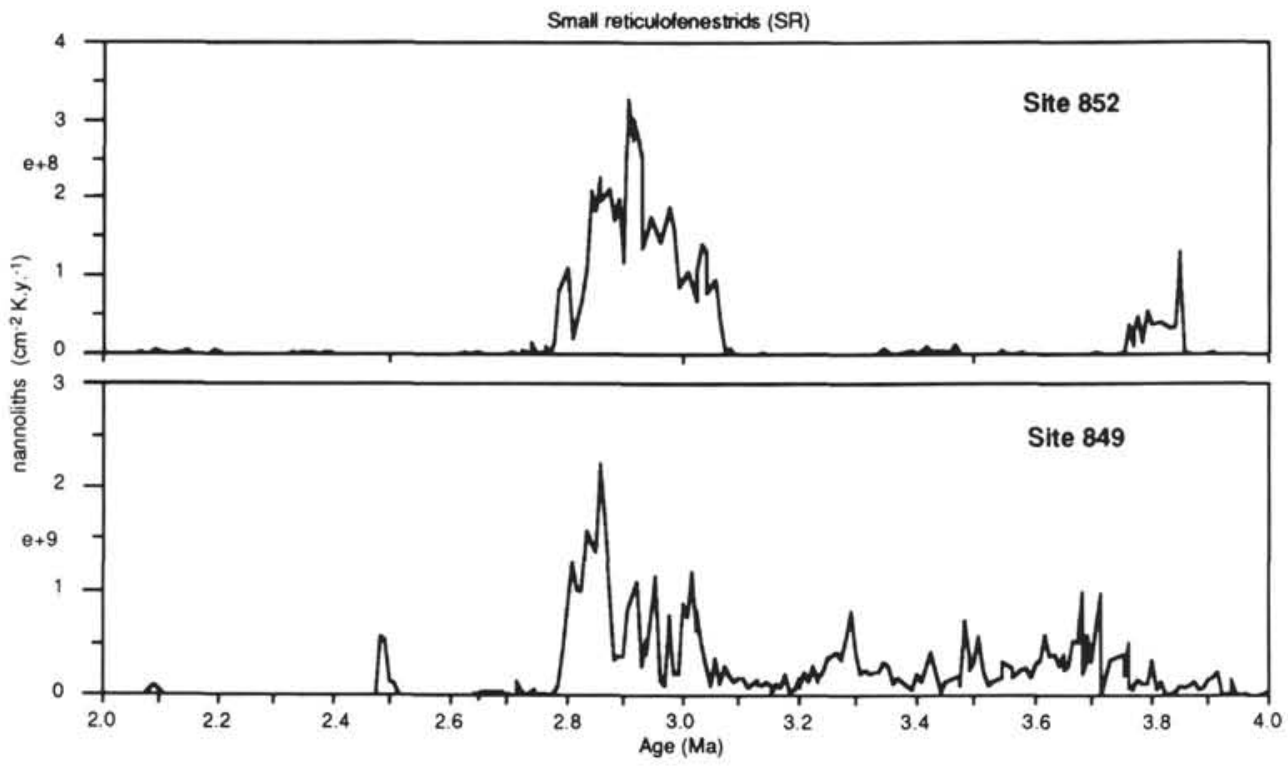

Figure 9. Small reticulofenestrid accumulation rates at Sites 849 and 852 between 4 and 2 Ma. For taxonomic information, see the Appendix and Table Al.

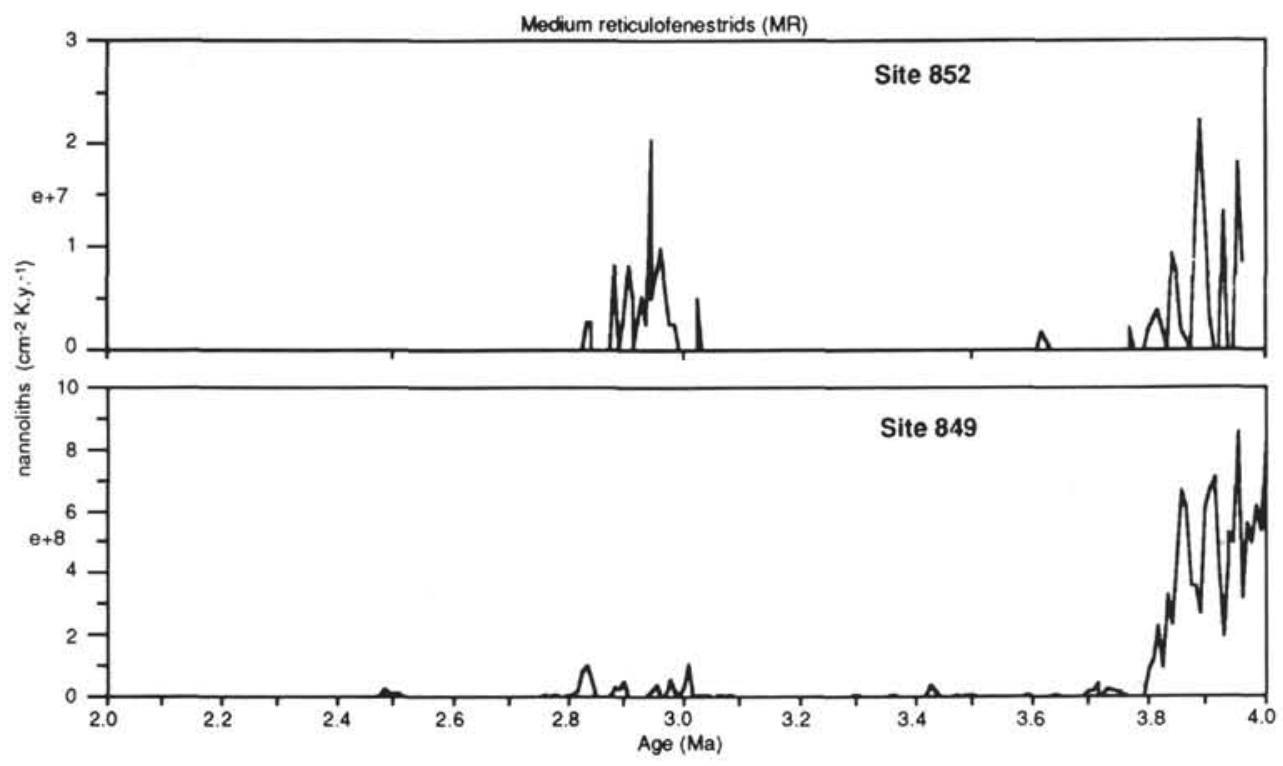

Figure 10. Medium reticulofenestrid accumulation rates at Sites 849 and 852 between 4 and 2 Ma. For taxonomic information, see the Appendix and Table Al.

$3.40,3.10$ to 2.80 , and a minor pulse is observed near $3.20 \mathrm{Ma}$. At Site 852 , in the younger interval, D. tamalis is less abundant. As from $2.70 \mathrm{Ma}$, the abundance of this species has been lower.

Discoaster surculus Martini and Bramlette shows a maximum from 3.50 to $2.90 \mathrm{Ma}$ at Site 852 . At Site 849 , this peak occurs from 3.60 to $3.0 \mathrm{Ma}$.

Discoaster pentaradiatus Tan does not exhibit meaningful changes in distribution in Site 849. At Site 852, two peaks are observed at 3.40 and between 3.10 and $2.80 \mathrm{Ma}$. This species is more abundant in Site 852 .

\section{Other Groups}

Characteristic nannofossiliferous groups, such as the ceratoliths and Syracosphaera have also been studied but are not the focus of this study.
The ceratoliths are more abundant in Site 852 than in Site 849 . Their distribution is uniform, with an accumulation rate peak at about 3.50 $\mathrm{Ma}$ in Site 849. Syracosphaera, an easily dissolved form, is relatively common. A significant increase is seen at about $2.80 \mathrm{Ma}$ in both sites.

\section{NANNOFOSSIL PRESERVATION AND REWORKING}

To evaluate the effect of dissolution on the nannofossil assemblages, we followed the model described by Rio et al. (1975) and Raffi and Flores (this volume). This scheme allows us to generate a quantitative estimation of dissolution similar to the one proposed by Dean et al. (1981). Moreover, assuming that dissolution should increase the relative abundance of the more resistant forms, such as the asteroliths (Ramsay, 1972, 1977; Ramsay et al., 1973; MacKenzie and Wise, 


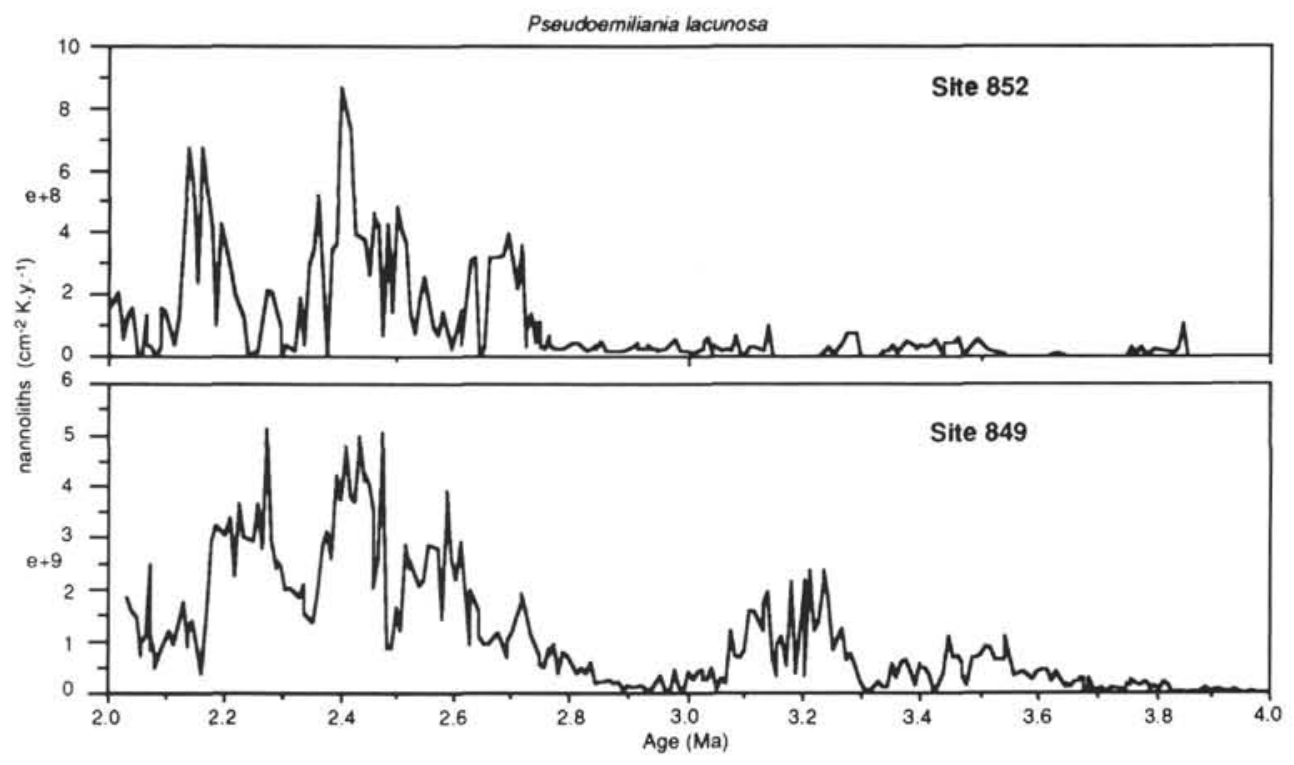

Figure 11. Pseudoemiliania lacunosa accumulation rates at Sites 849 and 852 between 4 and $2 \mathrm{Ma}$. For taxonomic information, see the Appendix and Table Al.

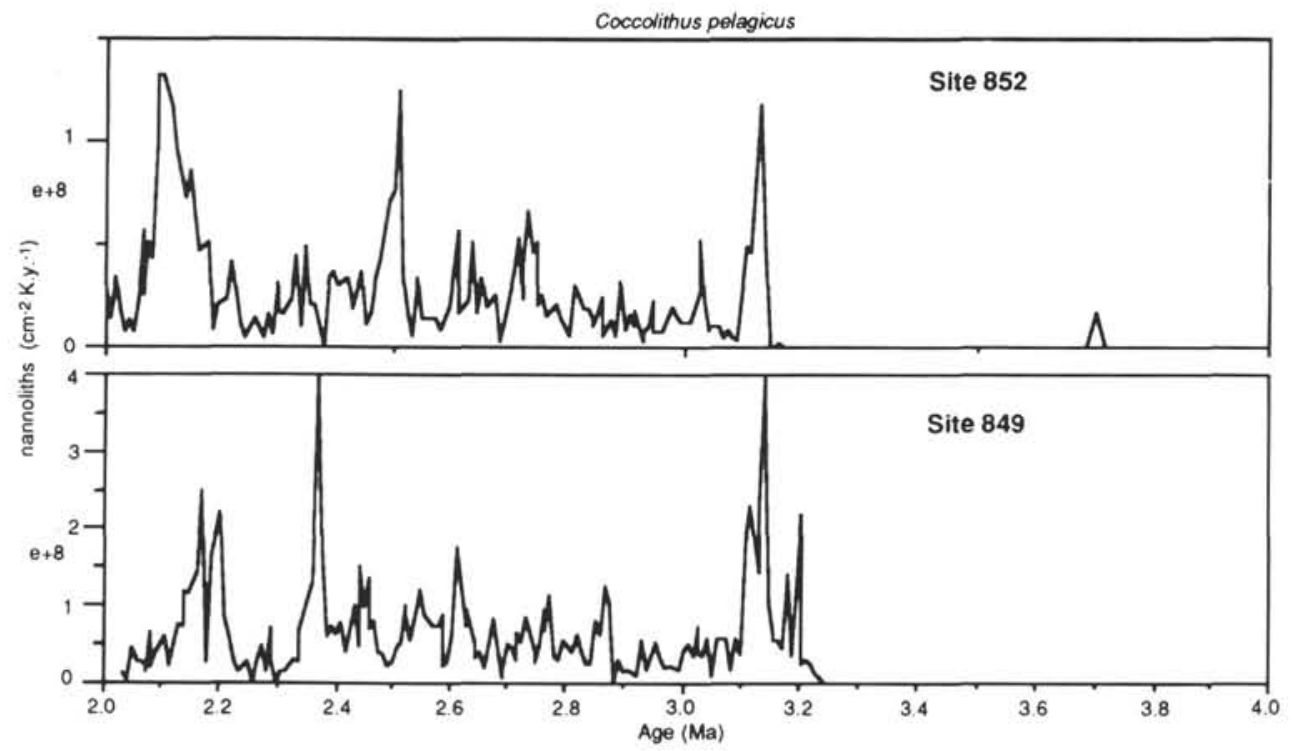

Figure 12. Coccolithus pelagicus accumulation rates at Sites 849 and 852 between 4 and $2 \mathrm{Ma}$.

1983, and Rio et al., 1990), we were able to calculate the percentage of this group in the nannofossil assemblage (Fig. 17). At Site 852, the intervals where nannofossils are corroded coincide with an increase in the percentage of asteroliths. The most dissolved intervals recorded at Site 852 are: 3.94 to $3.60,3.35$ to 3.15 and 2.32 to 2.21 Ma (Figs. 7 and 17). However, differences in the production rates of asteroliths in relation to other nannofossil groups could also influence the relative abundance of asteroliths in the assemblage, as will be discussed later.

At Site 849 , two intervals having moderate etching, but with the common presence of VSR and other easily dissolved forms (such as Syracosphaera), were observed from 3.35 to $2.99 \mathrm{Ma}$, and about 2.70 Ma. It should be stressed that these dissolved intervals do not correspond to high percentages of asteroliths because of the low production rates of this group (Fig. 7 and 17). This relative low abundance of asteroliths is probably due to changes in paleoceanographic and/or paleoclimatic parameters. In this sense, Farrell and Prell (1991) defined a similar pattern of dissolution due to transient changes in the carbonate system, such as in sea level, productivity, or circulation.

Pujos (1985) commented on the possible influence of bottom currents on the sediments at Site 575 in the eastern equatorial Pacific Ocean. At Site 852 , we observed with regularity the presence of reworked forms in the sediments deposited since the middle Miocene. This fact, together with the high percentage of planktonic foraminifers in some samples (Mayer, Pisias, Janecek, et al., 1992), suggests to us the possibility of winnowing in this region during the Neogene. The scarcity of reworked forms at Site 849 might be explained by their dilution in an environment of higher nannofossil accumulation rates.

\section{DISCUSSION}

The late Pliocene eastern equatorial Pacific Ocean is characterized by moderate sedimentation rates, following a period of higher accu- 


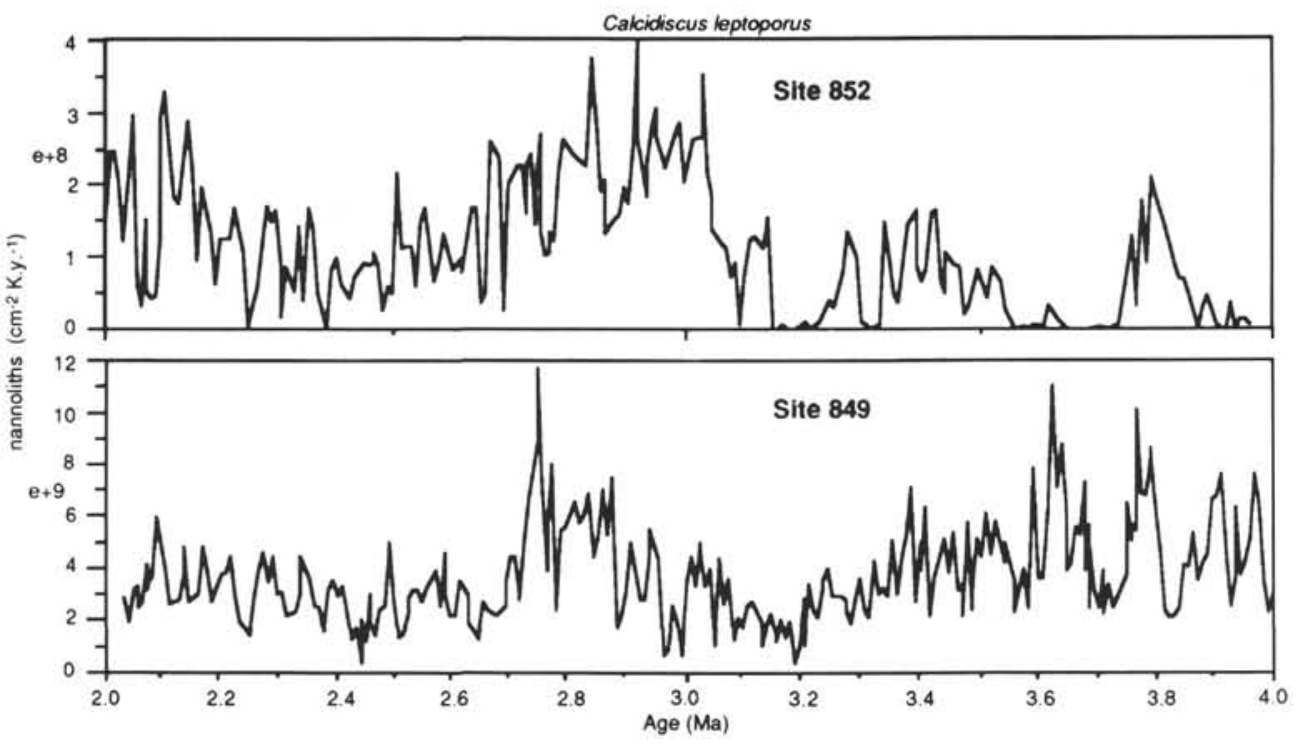

Figure 13. Calcidiscus leptoporus accumulation rates at Sites 849 and 852 between 4 and 2 Ma.

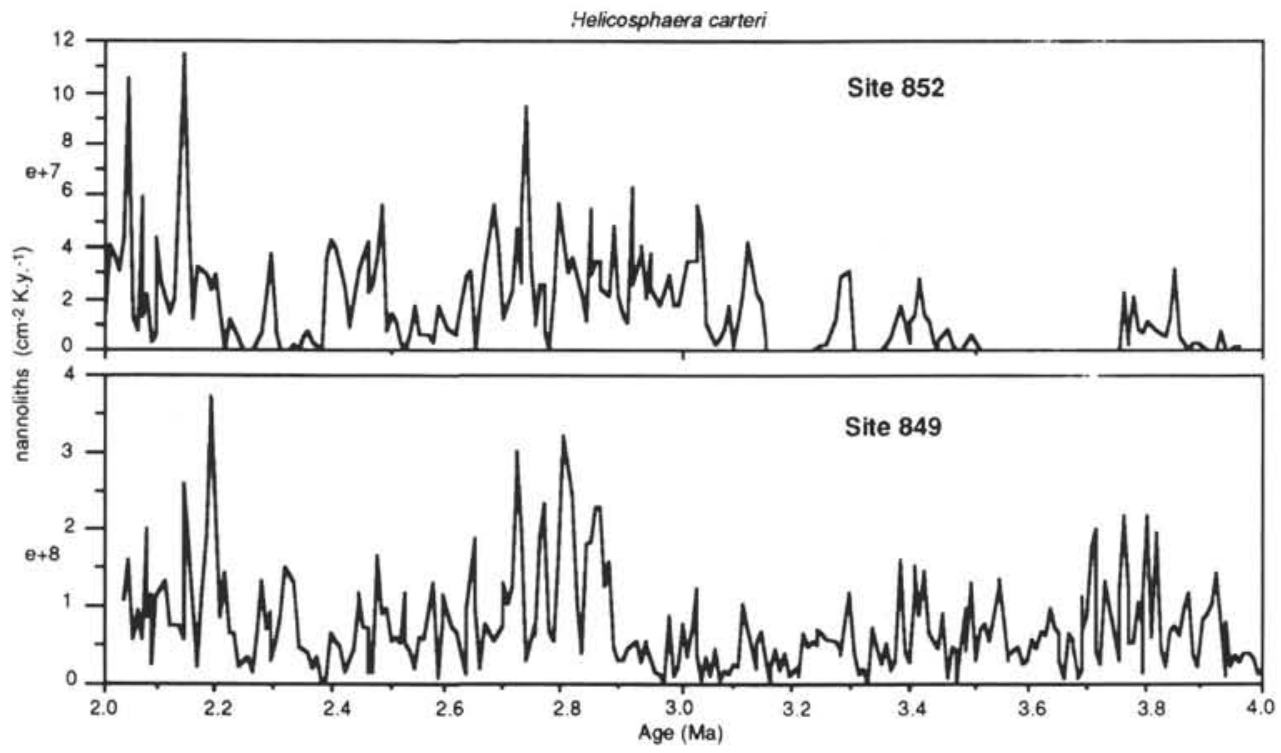

Figure 14. Helicosphaera carteri accumulation rates at Sites 849 and 852 between 4 and 2 Ma.

mulation rates within the early Pliocene and late Miocene (see Shackleton et al., this volume). An associated decrease in the calcium carbonate flux has been attributed to oceanographic changes linked to tectonic activity in the Panamanian seaway (Pisias and Prell, 1985a) or global events related to the sea level (Farrell and Prell, 1991).

The calcium carbonate accumulation in sediments depends on the ratio between the production rate in surface waters and the preservation rate at depth. The fluctuations in the $\mathrm{CaCO}_{3}$ content of the equatorial Pacific sediments during the Pleistocene are very known since the work of Arrhenius (1952). Different authors have analyzed the record of carbonate, opal, and carbon fluxes during the Pleistocene. Pisias and Rea (1988), and Farrel and Prell $(1989,1991)$ conclude that changes in bottom water corrosiveness may have played an important role in controlling the calcium carbonate accumulation in sediments. On the other hand, Lyle et al. (1988) and Rea et al. (1991) assume that primary productivity, rather than dissolution, has the major role regarding the accumulation of the different components in the equatorial sediments. For these latter authors, the calcium carbon- ate and organic carbon fluxes are well correlated and are good indicators of paleoproductivity.

The calcium carbonate MAR in the eastern equatorial Pacific is mainly controlled by the accumulation rates of the nannofossils and foraminifers. These rates are related to biogenic production of both planktonic groups and to taphonomic processes, such as dissolution or winnowing.

During the late Pliocene abundances of planktonic foraminifers ranged from $10 \%$ to $20 \%$ of the calcareous assemblages at Site 849 , and from $30 \%$ to $60 \%$ at Site 852 (Mayer, Pisias, Janecek, et al., 1992). One may therefore assume that the calcareous nannofossil accumulation rate represents from $40 \%$ to $90 \%$ of the calcium carbonate MAR. Thus, the correlation among GRAPE data, calcium carbonate content, and the concentration of nannofossils in the sediments should be better when the nannofossils/planktonic foraminifers ratio is higher. In fact, the correlation among the nannofossil content, carbonate MAR, and GRAPE data seems to be evident at both sites (Mayer, Pisias, Janecek, et al., 1992). 


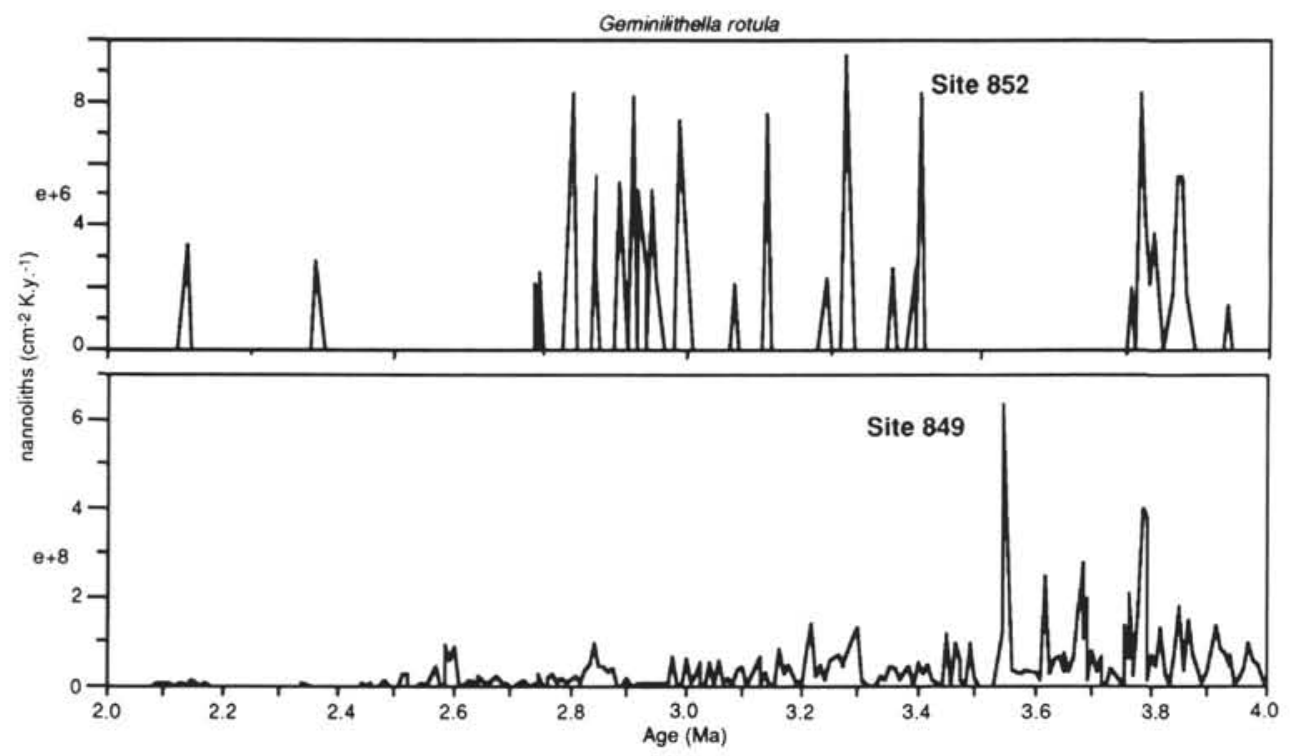

Figure 15. Geminilithella rotula accumulation rates at Sites 849 and 852 between 4 and 2 Ma.

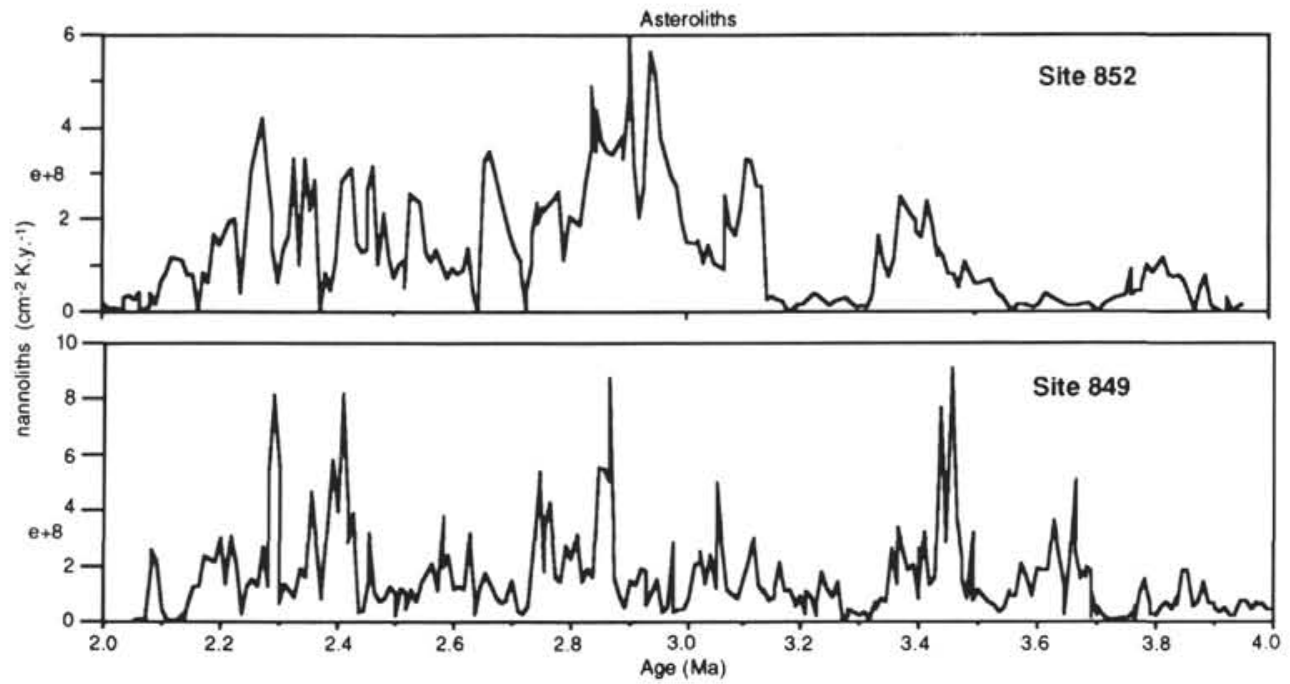

Figure 16. Asterolith accumulation rates at Sites 849 and 852 between 4 and $2 \mathrm{Ma}$. For taxonomic considerations, see the Appendix.

Because calcareous nannofossils are the primary producers tied to the nutrient content in surface waters, their mass accumulation rates should be an index of paleoproductivity. According to the above mentioned data, we assume that in periods or areas of higher productivity, higher nannofossil production rates would have diluted the planktonic foraminifer content in the calcareous assemblages. Likewise, dissolution may have contributed to the dilution effect by preferentially dissolving dissolution-susceptible foraminifers, but not dissolutionresistant nannofossils. Increased dissolution would have undoubtedly reduced the nannofossil MAR. On the other hand, the effect of bottom currents on the surface sediments may have caused a relative increase of foraminifers.

When comparing the nannofossil sedimentation rates at Sites 849 and 852 , we see that this equatorial site shows fluxes 10 times higher than those recorded in the northern site (Fig. 7). This is consistent with their respective locations in the high- and low-productivity belts of the eastern equatorial Pacific Ocean. Fluctuations in the nannofossil accumulation rate between 4 and $2 \mathrm{Ma}$ in both sites must probably record changes in surface productivity, dissolution intensity, and win- nowing. At Site 849, preservation is generally good, with the exception of some intervals where it is only moderate. These intervals are characterized by a relatively low flux of nannofossils. By contrast, preservation at Site 852 is generally poor, although strongly dissolved intervals alternate with well preserved ones (Figs. 7 and 17).

From 4 to $2 \mathrm{Ma}$, both sites were located between the lysocline and the $C C D$ as, may be deduced from the strong dissolution of planktonic foraminifers and good-to-moderate preservation in nannofossils. The CCD may have shoaled to the depth of Site 852 during times characterized by extremely poor nannofossil preservation. The increasing dissolution intensity from the divergence to the convergence regions may be explained by the shallowing of the $\mathrm{CCD}$, resulting from the decreasing calcite supply as productivity declines (Berger, 1971). In this setting, it is possible that the variations in the nannofossil accumulation rate of both sites have been mainly controlled by changes in surface productivity that, in turn, influence the position of the lysocline and CCD and, hence, the degree of dissolution in deep waters and surface sediments. Consequently, maxima in nannofossil accumulation rates may be related to maximum productivity in sur- 


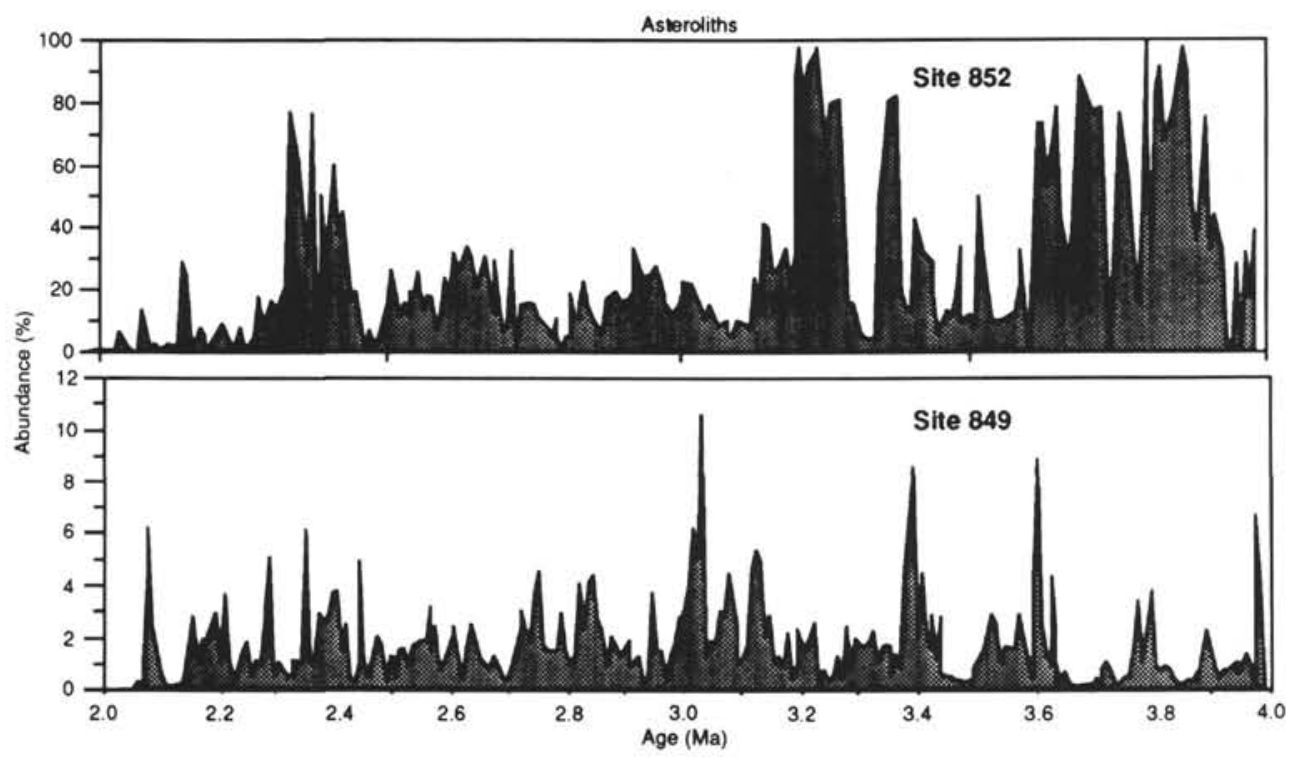

Figure 17. Relative abundance of the asteroliths in relation to the total number of nannofossils at Sites 849 and 852 from 4 to $2 \mathrm{Ma}$.

face waters. Intervals with lower sedimentation rates may have been related to times of lower productivity. This leads to longer residence times for calcite particles within the sediment and mixed layer enhancing the effect of biological reworking, resuspension by bottom currents, and dissolution.

Calcareous nannofossil assemblages were mainly controlled by VSR. For this reason, one may assume that this group is a good indicator of paleoproductivity, although at the same time these tiny forms are easily dissolved.

High abundance of asteroliths are traditionally related to warm waters (Haq and Lohmann, 1976) or low-nutrient content (ChepstowLusty et al., 1992). Unlike that observed in the VSR, the accumulation rates of asteroliths in Sites 849 and 852 vary within a similar range (Fig. 16). Moreover, a similar trend in the asterolith fluxes was observed between both sites, showing that maxima and minima values occur at the same time. Therefore, one can assume that these asteroliths do not respond to the higher nutrient content of the surface waters. They may be a relatively more abundant component of nannofossil assemblages in an oligotrophic environment due to the higher fluxes of the VSR (opportunistic taxa) in the equatorial divergence region, because they are more sensitive to the higher nutrient content of these waters (Fig. 17).

On average, the relative abundance of the asteroliths at Site 852 is 10 times higher than that recorded at Site 849 (Fig. 16). The higher abundances in Site 852 in the intervals between 3.94 and 3.60, 3.35 and 3.15 , and from 2.32 to $2.21 \mathrm{Ma}$ are clearly due to asterolith concentration by strong dissolution (Fig. 17). In other intervals from Site 852 and in almost the entire interval at Site 849, dissolution is not clearly evident; however, percentages are higher in the northern site. This fact may be explained by the higher production rates of the VSR in the equatorial site which dilute the asteroliths in the nannofossil assemblage. According to shipboard data, planktonic foraminifers also are relatively more abundant in relation to nannofossils at Site 852 (Mayer, Pisias, Janecek, et al., 1992). Planktonic foraminifers are generally less resistant to dissolution than nannofossils and hence the lower relative abundances of planktonic foraminifers in the equatorial region must also be explained by dilution, as was the case of the asteroliths. This reinforces the aforementioned assumption that productivity, rather than dissolution, is the main factor controlling the higher or lower relative abundance of asteroliths in nannofossil assemblages.

Other characteristic species, such as C. leptoporus and H. carteri, follow a similar trend to that observed in the VSR. This observation supports the comment of Pujos (1992) who inferred that $H$. carteri could be a productivity indicator in the Northeast Atlantic coastal upwelling system.

Coccolithus pelagicus, usually linked to cool waters (Okada and McIntyre, 1979; Bukry, 1980), is absent in this area until 3.20 Ma at Site 849 and $3.17 \mathrm{Ma}$ at Site 852 . This minor diachronism may be due to the dissolution observed in this interval at Site 852. At about 3.20 $\mathrm{Ma}$, a strong meridional circulation system became established with well-defined northward and southward currents potentially introducing cool species into the nannofossil assemblages. This event may have coincided with a major restriction of the Atlantic-Pacific connection through the Panamanian Gateway (Coates et al., 1992). Dowsett et al. (1993) suggested that an increase in meridional heat transport occurred in the North Atlantic at approximately this time. The above-mentioned data suggest a similar event happening in the Pacific Ocean. According to these data, an increase in thermohaline circulation might have been responsible for a change in bottom-water chemistry in the Pacific Ocean, causing the rise in the CCD. Taking into account the oxygen isotope data of Prell (1985) and Farrel and Prell (1989) for eastern equatorial Pacific Sites 572 and 573, the marked peaks of $C$. pelagicus at about 3.15 Ma in our sites strikingly coincide with a notable increase in $\delta^{18} \mathrm{O}$ values at this time. Labreque et al. (1977) magnetostratigraphic ages were converted to Shackleton et al.'s (this volume) ages.

The abundance of $P$. lacunosa was low until $2.80 \mathrm{Ma}$ in both sites (with the exception of an interval between 3.30 and $3.05 \mathrm{Ma}$ at Site $849)$, but increased markedly after this time. The variations observed in this species follow a trend similar to that seen in $C$. pelagicus and, hence, it must be assumed that $P$. lacunosa in some way is linked to the cool oceanographic conditions that developed after 3.30 Ma. In this interval, other relatively cool species, such as $D$. tamalis and $D$. asymmetricus (Rio et al., 1989), exhibited a relative increase (Fig. 5). Shackleton and Opdyke (1977), Keigwin (1982, 1987), Dowsett and Poore (1991) and others discuss an important $\delta^{18}$ O enrichment at 3.35 $\mathrm{Ma}$ (Shackleton et al.'s age), which, as seen, marks the base of an interval where P. lacunosa is relatively abundant. Prell (1985) recognized another $\delta^{18} \mathrm{O}$ enrichment in the interval between 2.55 to 2.41 $\mathrm{Ma}$ that was also related to a strong increase in the $P$. lacunosa sedimentation rate in Sites 849 and 852 (Fig. 11).

The SR and MR show a pattern opposite to that observed in $P$. lacunosa. Note the increase of these groups between 3.02 and 2.76 $\mathrm{Ma}$ at both sites, coinciding exactly with the minima values of $P$. lacunosa. This similarity in time distribution leads us to suggest that these groups may have played a similar ecologic role in different 
Table 1. Calcareous nannofossil events and calibrated ages according to the scale of Shackleton et al. (this volume).

\begin{tabular}{|c|c|c|c|}
\hline \multirow[b]{2}{*}{ Nannofossil event } & \multicolumn{3}{|c|}{ Age (Ma) } \\
\hline & Site 849 & Site 852 & $\begin{array}{c}\text { Shackleton et al. } \\
\text { (this volume) }\end{array}$ \\
\hline LAD R. pseudoumbilicus & 3.80 & 3.82 & 3.81 \\
\hline Drop of MR & 3.70 & 3.75 & \\
\hline LAD Sphenolithus & 3.67 & 3.71 & 3.65 \\
\hline LAD D. variabilis Group & 3.44 & 3.42 & \\
\hline Reentry of $C$. pelagicus & 3.20 & 3.17 & \\
\hline D. decorus/pansus reentry peak & $3.08-3.18$ & 3.043 .17 & \\
\hline Reentry of MR & $3.02-2.76$ & $3.02-2.86$ & \\
\hline LAD D, tamalis & 2.77 & 2.79 & 2.76 \\
\hline LAD D. surculus & 2.52 & 2.52 & 2.52 \\
\hline LAD D. pentaradiatus & 2.48 & 2.48 & 2.52 \\
\hline $\mathrm{BA} D$, triradiatus & 2.21 & 2.16 & \\
\hline$H$, sellii peak & 2.15 & 2.09 & \\
\hline
\end{tabular}

Notes: $\mathrm{LAD}=$ last appearance datum; $\mathrm{BA}=$ bottom acme: $\mathrm{MR}=$ medium reticulofenestrids. Asterisks mark unconventional events.

paleoceanographic contexts. When conditions changed during the late Pliocene, one replaced the other.

According to the previously mentioned data, the lowest productivities during late Pliocene eastern equatorial Pacific Ocean occurred between 3.30 and 3.10 and from 2.60 to $2.50 \mathrm{Ma}$. As already discussed, these intervals were also characterized by cool climatic conditions. However, a more detailed correlation between variations in productivity and climatic change will be possible when the isotope data for these sites become available.

\section{CONCLUSIONS}

Maxima in fluxes of nannofossils are observed from 3.50 to 3.40 , and 3.10 to $2.65 \mathrm{Ma}$ in Sites 849 and 852 . These peaks are interpreted as periods of high productivity. Changes in paleoproductivity seem to be the most important factor to explain the variations in fluxes. Dissolution is also important, but is controlled by the calcium carbonate production, which in this region is mainly due to nannofossils.

Site 849 , located in an area of oceanic divergence, shows fluxes of nannofossils 10 times higher than those recorded at Site 852, situated in an area of oceanic convergence. The lower productivity observed at Site 852 determines a more intense dissolution as a consequence of the minor supply of phytoplanktonic calcium carbonate. In general, the dissolved intervals are characterized by a relative increase of asteroliths.

The fluxes of asteroliths are similar in divergence and convergence areas. However, because of the increase of the VSR in the divergence area, the relative proportion of asteroliths is higher in the lower nutrient content environment (convergence area).

During the late Pliocene, the paleoproductivity indicators in two sites with very different oceanographic conditions (divergence in Site 849 and convergence in Site 852) followed the same pattern (taking into account differences in general preservation). Increases or decreases in paleoproductivity have changed synchronously. These data lead us to suggest that a regional model, rather than a local one, may better explain the variations in paleoproductivity in the eastern equatorial Pacific Ocean.

The reentry of $C$. pelagicus, and the increase of $P$. lacunosa at 3.20 $\mathrm{Ma}$, is related to the onset of a strong meridional circulation system in the Pacific Ocean that coincides with a global cooling.

\section{ACKNOWLEDGMENTS}

We thank Domenico Rio and Wuchang Wei for their valuable suggestions and critical reviewing of the original version of this manuscript, and Sondra Stewart and Nick Skinner for English corrections. We are especially grateful to our shipboard colleagues Ted Moore and John Farrell for scientific and linguistic comments. Guillermo Francés, who assisted us in performing figures with the computer, also is acknowledged. We also thank the international Ocean Drilling Pro- gram for providing material for this study. Special thanks go to Jesús Roncero for assisting in the difficult task of processing samples, and to the ODP colleagues and technicians for the hard sampling sessions.

This study was supported by DGICYT Project Nos. PB91-009702 and GEO 1272190-E, and the Universidad de Salamanca Grant No. 092 ACR7.

\section{REFERENCES $*$}

Arrhenius, G.O.S., 1952. Sediment cores from the east Pacific. Rep. Swed. Deep Sea Exped. 1947-1948, 119-146.

Backman, J., and Pestiaux, P., 1987. Pliocene Discoaster abundance variations, Deep Sea Drilling Project Site 606: biochronology and paleoenvironmental implications. In Ruddiman, W.F., Kidd, R.B., Thomas, E., et al., Init. Repts. DSDP, 94 (Pt. 2): Washington (U.S. Govt. Printing Office), 903-910.

Backman, J., Pestiaux, P., Zimmerman, H., and Hermelin, J.O.R., 1986. Palaeoclimatic and palaeoceanographic development in the Pliocene North Atlantic: Discoaster accumulation and coarse fraction data. In Summerhayes, C.P., and Shackleton, N.J. (Eds.), North Atlantic Palaeoceanography. Geol. Soc. Spec. Publ. London, 21:231-241.

Backman, J., and Shackleton, N.J., 1983. Quantitative biochronology of Pliocene and early Pleistocene calcareous nannofossils from the Atlantic, Indian and Pacific oceans. Mar. Micropaleontol., 8:141-170.

Berger, A., and Loutre, M.F., 1991. Insolation values for the climate of the last 10 million years. Quat. Sci. Rev., 10:297-317.

Berger, W.H., 1971. Sedimentation of planktonic foraminifera. Mar. Geol., 11:325-358.

Bukry, D., 1973. Low-latitude coccolith biostratigraphic zonation. In Edgar, N.T., Saunders, J.B., et al., Init. Repts. DSDP, 15: Washington (U.S. Govt. Printing Office), 685-703.

, 1980. Coccolith stratigraphy, tropical eastern Pacific Ocean, Deep Sea Drilling Project Leg 54. In Rosendahl, B.R., Hekenian, R., et al., Init. Repts. DSDP, 54: Washington (U.S. Govt. Printing Office), 535-543.

Chavez, F.P., and Barber, R.T., 1987. An estimate of new production in the equatorial Pacific. Deep-Sea Res. Part A, 34:1229-1243.

Chepstow-Lusty, A., Backman, J., and Shackleton, N.J., 1989. Comparison of upper Pliocene Discoaster abundance variations from North Atlantic Sites $552,607,658,659$ and 662 : further evidence for marine plankton responding to orbital forcing. In Ruddiman, W.F., Sarnthein, M., et al., Proc. ODP, Sci. Results, 108:College Station, TX (Ocean Drilling Program), 121-141.

Chepstow-Lusty, A., Shackleton, N.J., and Backman, J., 1992. Upper Pliocene Discoaster abundance from the Atlantic, Pacific, and Indian oceans: the significance of productivity pressure at low latitudes. Mem. Sci. Geol., 44:357-373.

Coates, A.G., Jackson, J.B., Collins, L.S., Cronin, T.M., Dowsett, H.J., Bybell, L.M., Jung, P., and Obando, J.A., 1992. Closure of the Isthmus of Panama: the near-shore marine record of Costa Rica and Western Panama. Geol. Soc. Am. Bull., 104:814-828.

Dean, W.E., Gardner, J.V., and Cepek, P., 1981. Tertiary carbonate-dissolution cycles on the Sierra Leone Rise, eastern Equatorial Atlantic Ocean. Mar. Geol., 39:81-101.

Dowsett, H.J., Cronin, T.M., Poore, R.Z., Thompson, R.S., Whatley, R.C., and Wood, A.M., 1993. Micropaleontological evidence for increase meridional heat transport in the North Atlantic during the Pliocene. Science, 258:1133-1135.

Dowsett, H.J., and Poore, R.Z., 1991. Pliocene sea surface temperatures of the North Atlantic Ocean at 3.0 Ma. Quat. Sci. Rev., 10:189-204.

Duncan, R.A., and Clague, D.A., 1985. Pacific plate motion recorded by linear volcanic chains. In Nairn, A.E.M., Stehli, F.G., and Uyeda, S. (Eds.), The Ocean Basins and Margins (Vol. 7A): The Pacific Ocean: New York (Plenum), 89-121.

Farrell, J.W., and Prell, W.L., 1989. Climatic change and $\mathrm{CaCO}_{3}$ preservation: an 800,000 year bathymetric reconstruction from the central equatorial Pacific Ocean. Paleoceanography, 4:447-466.

, 1991. Pacific $\mathrm{CaCO}_{3}$ preservation and $\delta^{\mathrm{i}} \mathrm{O}$ since $4 \mathrm{Ma}$ : paleoceanic and paleoclimatic implications. Paleoceanography, 6:485-498.

Flores, J.A., and Sierro, F.J., 1989. Calcareous nannoflora and planktonic foraminifera in the Tortonian-Messinian boundary interval of East Atlantic DSDP sites and their relation to Spanish and Moroccan sections. In Crux,

\footnotetext{
Abbreviations for names of organizations and publication titles in ODP reference lists follow the style given in Chemical Abstracts Service Source Index (published by American Chemical Society).
} 
J.A., and van Heck, S.E. (Eds.), Nannofossils and Their Applications: Chichester (Ellis Horwood), 249-266.

Gallagher, L., 1989. Reticulofenestra: a critical review of taxonomy, structure and evolution. In Crux, J.A., and van Heck, S.E. (Eds.), Nannofossils and Their Applications: Chichester (Ellis Horwood), 41-75.

Hagelberg, T., Shackleton, N., Pisias, N., and Shipboard Scientific Party, 1992. Development of composite depth sections for Sites 844 through 854. In Mayer, L., Pisias, N., Janecek, T., et al., Proc. ODP, Init. Repts., 138 (Pt. 1): College Station, TX (Ocean Drilling Program), 79-85.

Haq, B.U., and Lohmann, G.P., 1976. Early Cenozoic calcareous nannoplankton biogeography of the Atlantic Ocean. Mar. Micropaleontol., 1:119-194.

Keigwin, L.D., Jr., 1982. Basis for age assignments at Deep Sea Drilling Project Sites 502-503. In Prell, W.L., Gardner, J.V., et al., Init. Repts. DSDP, 68: Washington (U.S. Govt. Printing Office), 493-495.

1987. Pliocene stable-isotope record of Deep Sea Drilling Project Site 606: sequential events of ${ }^{18} \mathrm{O}$ enrichment beginning at $3.1 \mathrm{Ma}$. In Ruddiman, W.F., Kidd, R.B., Thomas, E., et al., Init. Repts. DSDP, 94 (Pt. 2): Washington (U.S. Govt. Printing Office), 911-920.

LaBrecque, J.L., Kent, D.V., and Cande, S.C., 1977. Revised magnetic polarity time scale for Late Cretaceous and Cenozoic time. Geology, 5:330-335.

Lyle, M., Murray, D.W., Finney, B.P., Dymond, J., Robbins, J.M., and Brooksforce, K., 1988. The record of late Pleistocene biogenic sedimentation in the eastern tropical Pacific Ocean. Paleoceanography, 3:39-59.

MacKenzie, D.T., III, and Wise, S.W., Jr., 1983. Paleocene and Eocene calcareous nannofossils from Deep Sea Drilling Project Legs 25 and 40, south and east of Africa. In Ludwig, W.J., Krasheninnikov, V.A., et al., Init. Repts. DSDP, 71: Washington (U.S. Govt. Printing Office), 1141-1169.

Mayer, L., Pisias, N., Janecek, T., et al., 1992. Proc. ODP, Init. Repts., 138 (Pts. 1 and 2): College Station, TX (Ocean Drilling Program).

Okada, H., and McIntyre, A., 1979. Seasonal distribution of the modern Coccolithophores in the western North Atlantic Ocean. Mar. Biol.. 54:319-328.

Patterson, R.T., and Fishbein, E., 1989. Re-examination of the statistical methods used to determine the number of point counts needed for micropaleontological quantitative research. J. Paleontol., 63:245-248.

Pisias, N.G., and Prell, W.L., 1985a. Changes in calcium carbonate accumulation in the Equatorial Pacific during the late Cenozoic: evidence from HPC Site 572. In Sundquist, E.T., and Broecker, W.S. (Eds.), The Carbon Cycle and Atmospheric $\mathrm{CO}_{2}$ : Natural Variations Archean to Present. Am. Geophys. Union, 443-454.

, 1985b. High resolution carbonate records from the hydraulic piston cored section of Site 572. In Mayer, L., Theyer, F., Thomas, E., et al., Init. Repts. DSDP, 85: Washington (U.S. Govt. Printing Office), 711-722.

Pisias, N., and Rea, D.K., 1988. Late Pleistocene paleoclimatology of the central equatorial Pacific: sea surface response to the southeast trade winds. Paleoceanography, 3:21-37.

Prell, W.L., 1985. Pliocene stable isotope and carbonate stratigraphy (Holes $572 \mathrm{C}$ and 573A): paleoceanographic data bearing on the question of Pliocene glaciation. In Mayer, L., and Theyer, F., Thomas, E., et al., Init. Repts. DSDP, 85: Washington (U.S. Govt. Printing Office), 723-734.

Pujos, A., 1985. Cenozoic nannofossils, central equatorial Pacific, Deep Sea Drilling Project Leg 85. In Mayer, L., Theyer, F., Thomas, E., et al., Init. Repts. DSDP, 85: Washington (U.S. Govt. Printing Office), 581-607.

1992. Calcareous nannofossils of Plio-Pleistocene sediments from the northwestern margin of tropical Africa. In Summerhayes, C.P., Prell, W.L., and Emeis, K.C. (Eds.), Upwelling Systems: Evolution Since the Early Miocene. Geol. Soc. Spec. Publ. London, 64:343-359.

Ramsay, A.T.S., 1972. Aspects of the distribution of fossil species of calcareous nannoplankton in North Atlantic and Caribbean sediments. Nature, 236:67-70.

, 1977. Sedimentological clues to paleoceanography. In Ramsay, A.T.S. (Ed.), Oceanic Micropaleontology (Vol. 2): New York (Academic Press), 1371-1453.

Ramsay, A.T.S., Schneidermenn, N., and Finch, J.W., 1973. Fluctuations in the past rates of carbonate solution at Site 149: a comparison with other ocean basins and an interpretation of their significance. In Edgar, N.T., Saunders, J.B., et al., Init. Repts. DSDP, 15: Washington (U.S. Govt. Printing Office), 805-811.

Rea, D.K., Pisias, N.G., and Newberry, T., 1991. Late Pleistocene paleoclimatology of the central Equatorial Pacific: flux patterns of biogenic sediments. Paleoceanography, 6:227-244.
Rio, D., Fornaciari, E., and Raffi, 1., 1990. Late Oligocene through early Pleistocene calcareous nannofossils from western equatorial Indian Ocean (Leg 115). In Duncan, R.A., Backman, J., Peterson, L.C., et al., Proc. ODP, Sci. Results, 115: College Station, TX (Ocean Drilling Program), 175-235.

Shackleton, N.J., and Opdyke, N.D., 1977. Oxygen isotope and palaeomagnetic evidence for early Northern Hemisphere glaciation. Nature, 270:216-219.

Shackleton, N.J., and Shipboard Scientific Party, 1992. Sedimentation rates: toward a GRAPE density stratigraphy for Leg 138 carbonate sections. In Mayer, L., Pisias, N., Janecek, T., et al., Proc. ODP, Init. Repts., 138 (Pt. 1): College Station, TX (Ocean Drilling Program), 87-91.

Theyer, F., Mayer, L.A., Barron, J.A., and Thomas, E., 1985. The equatorial Pacific high-productivity belt: elements for a synthesis of Deep Sea Drilling Project Leg 85 results. In Mayer, L., Theyer, F., Thomas, E., et al., Init. Repts. DSDP, 85: Washington (U.S. Govt. Printing Office), 971-985. van Andel, T.H., Heath, G.R., and Moore, T.C., Jr., 1975. Cenozoic history and paleoceanography of the central equatorial Pacific Ocean. Mem.-Geol. Soc. Am., 143.

Wei, W., 1988. A new technique for preparing quantitative nannofossil slides. J. Paleontol., 62:472-473.

1990. Clarification of Reticulofenestra perplexa (Burns) Wise, 1983. INA Newsl., 12:14-16.

Young, J., 1990. Size variation of Neogene Reticulofenestra coccoliths from Indian Ocean DSDP Cores. J. Micropaleontol., 9:71-86.

\section{Date of initial receipt: 3 March 1993 \\ Date of acceptance: 15 November 1993 Ms 138SR-109}

\section{APPENDIX}

Some comments concerning the most significant groups are herein discussed to clarify the taxonomic guidelines followed in this study.

\section{Reticulofenestrids}

Here, we have followed the general guidelines presented by Flores and Sierro (1989), Gallagher (1989), Young (1990), and Wei (1991), but only exceptional taxonomic categories were considered. Indeed, a morphological and biometrical division was made to develop a useful taxonomic scheme. The equivalent species with the considered categories (VSR, SR, MR, and LR) are Pseudoemiliania lacunosa (Kamptner) Gartner, Reticulofenestra minuta Roth, Reticulofenestra minutula (Gartner) Haq and Berggren, Reticulofenestra haqii Backman, Reticulofenestra pseudoumbilicus (Gartner) Gartner, Dictyococcites productus (Kamptner) Backman, and Dictyococcites antarcticus $\mathrm{Haq}=$ Reticulofenestra perplexa $($ Burns) Wise (see Table A1).

Small circular forms have not been differentiated from the very small elliptical forms because microscope resolution precludes a clear separation.

\section{Asteroliths}

\section{Discoaster brouweri Group}

In this group, we considered no bifurcated hexaradiated forms having different ray thickness. Discoaster brouweri Tan emend. Bramlette and Riedel s.s. and Discoaster intercalaris Bukry are included. The LAD of D. brouweri in Site 849 was difficult to define because a strong reduction in abundance was detected above $2.1 \mathrm{Ma}$. However, the LO has been placed later (Raffi and Flores, this volume).

\section{Discoaster variabilis Group}

In this group, Discoaster variabilis Martini and Bramlette s.s., together with other forms morphologically close, such as Discoaster decorus (Bukry) Bukry and Discoaster pansus (Bukry) Bukry, are included. Bukry (1973) and Rio et al. (1990) mentioned its record in contemporary levels in the Pacific and Indian oceans. During late Pliocene in the eastern equatorial Pacific Ocean, $D$. decorus was the most significant form; only a few specimens of the species $D$. pansus have been recorded. 
Table A1. Terminology used for the reticulofenestrids and their taxonomic equivalences.

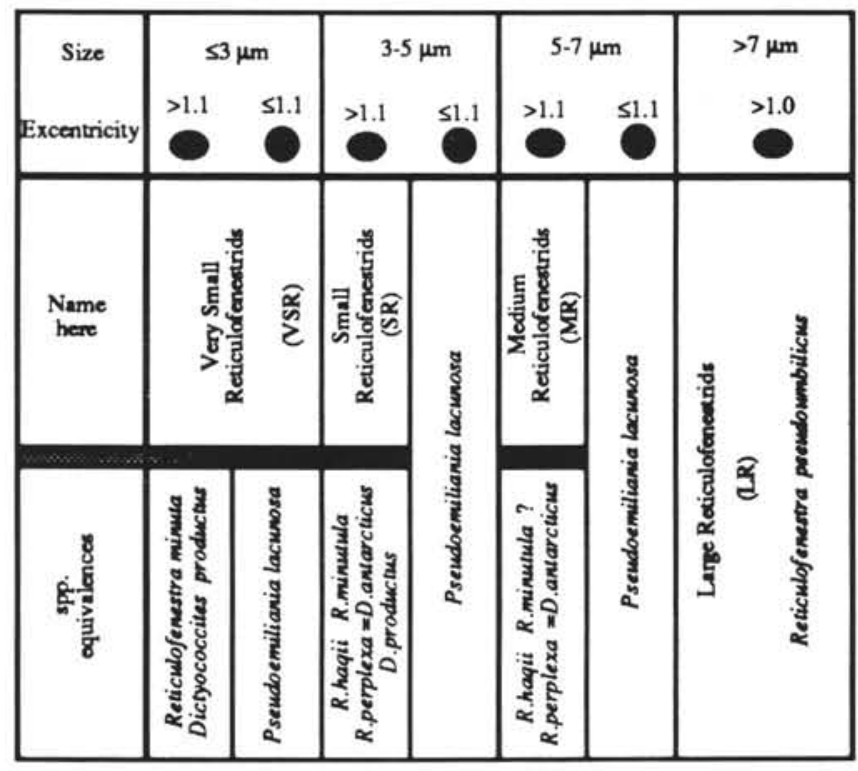

